\title{
Comparison of polystyrene nanoparticles and UV-inactivated antigen-displaying adenovirus for vaccine delivery in mice
}

\author{
Lena Johrden", Matthias Tenbusch', Ruth Lietz', Michael Storcksdieck genannt Bonsmann', Thomas Niezold', \\ Oliver Wildner ${ }^{1,3}$ and Wibke Bayer ${ }^{1,2^{*}}$
}

\begin{abstract}
Background: Inert nanoparticles are attracting attention as carriers for protein-based vaccines. Here we evaluate the immunogenicity of the model antigen ovalbumin delivered on polystyrene particles and directly compare particulate delivery with adenovirus-based immunization.

Findings: Mice were vaccinated with soluble ovalbumin, ovalbumin-coated polystyrene particles of different sizes, or an adenovirus-based expression-display vector that encodes and displays a plX-ovalbumin fusion protein. Antibody responses were clearly higher when ovalbumin was administered on polystyrene particles compared to soluble protein administration, regardless of the particle size. Compared to adenovirus-based immunization, antibody levels were lower if an equivalent amount of protein was delivered, and no cellular immune response was detectable.

Conclusions: We demonstrate in a side-by-side comparison that inert nanoparticles allow for the reduction of the administered antigen amount compared to immunization with soluble protein and induce strongly enhanced antibody responses, but responses are lower compared to adenovirus-based immunization.
\end{abstract}

Keywords: Nanoparticles, Polystyrene, Adenovirus, Ovalbumin, Vaccination

\section{Main text}

Protein and peptide vaccines are generally regarded as safe; however, in most cases they require the coadministration of adjuvants to be effective, which may in turn cause adverse events [1]. Therefore it is desirable to develop safe and clinically effective non-adjuvanted vaccines, and one approach is the use of nano- or microparticles coated with antigen, which can enhance immunogenicity compared to soluble antigen [2-4]. In this study we analyzed polystyrene particles coated with the model antigen ovalbumin for their potency at inducing humoral and cellular responses. As adenoviral (Ad) vectors are very popular for vaccine development because of their high immunogenicity and strong immune responses

\footnotetext{
*Correspondence: wibke.bayer@uni-due.de

'Department of Molecular and Medical Virology, Ruhr-University Bochum, Bochum, Germany

${ }^{2}$ Institute for Virology, University Hospital Essen, University Duisburg-Essen, Essen, Germany

Full list of author information is available at the end of the article
}

to the delivered vaccine antigens, we made side-by-side comparisons of coated polystyrene particles of varying sizes with an Ad expression-display vector, which we showed before to induce especially good $\mathrm{CD}^{+} \mathrm{T}$ cell and antibody responses [5].

Carboxyl-modified polystyrene beads of 24, 60, 93, 220 and $340 \mathrm{~nm}$ in diameter (BangsLabs/Polysciences, Fishers, IN) were loaded with recombinant ovalbumin (Sigma, Munich, Germany) by the carbodiimide method [6], and antigen loading was verified by dot blot and enzyme-linked immunosorbent assay (ELISA; data not shown). For immunization experiments, 8-9 weeks old C57BL/6 mice (Élevage Janvier, Le Genest St Isle, France) were used. Mice were treated in accordance with the regulations and guidelines of the Institutional Animal Care and Use Committee of the Ruhr University Bochum, Germany.

To determine the best route of administration for particle-based immunization, mice received $5 \mu \mathrm{g}$ of

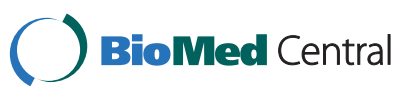


soluble ovalbumin or ovalbumin loaded on polystyrene particles diluted in $100 \mu \mathrm{l}$ sterile PBS by intramuscular, subcutaneous, or intraperitoneal injection, or by intradermal injection into both hind footpads. Ovalbumin-specific antibody levels were determined two weeks after immunization by ELISA [7] using ECL substrate (Alpha Innotech, San Leandro, USA) for luminometric readout. Soluble ovalbumin only induced a significant antibody level after immunization by intramuscular injection, but not the other routes, whereas all particles induced ovalbumin-binding antibodies regardless of the immunization route (Figure 1A). Antibody levels induced by ovalbuminloaded particles were significantly higher than after immunization with soluble ovalbumin (Figure 1A). Next, we analyzed the amount of protein necessary for the induction of detectable antibody levels. For this, mice were immunized once by intramuscular injection with $50 \mathrm{ng}$, $500 \mathrm{ng}$, or $5 \mu \mathrm{g}$ of ovalbumin, either as soluble protein or coupled to $93 \mathrm{~nm}$ polystyrene particles. While $5 \mu \mathrm{g}$ of soluble ovalbumin were necessary to induce measurable IgG1 antibody titers, $500 \mathrm{ng}$ on $93 \mathrm{~nm}$ particles were sufficient to induce high levels of IgG1 (Figure 1B). Antibodies of IgG2c subtype were not induced in detectable amounts by either vaccination strategy (Figure $1 \mathrm{C}$ ).

To analyze whether the induction of antibodies by protein-loaded polystyrene particles is dependent on $\mathrm{CD}^{+} \mathrm{T}$ cell help, mice were immunized twice with 93 $\mathrm{nm}$ polystyrene particles delivering the intermediate amount of $500 \mathrm{ng}$ ovalbumin, and depleted of $\mathrm{CD} 4^{+} \mathrm{T}$ cells around both time points of immunization by intraperitoneal injection of a CD4 antibody [8]. After mice were depleted of $\mathrm{CD} 4^{+}$cells during vaccination, no IgG1
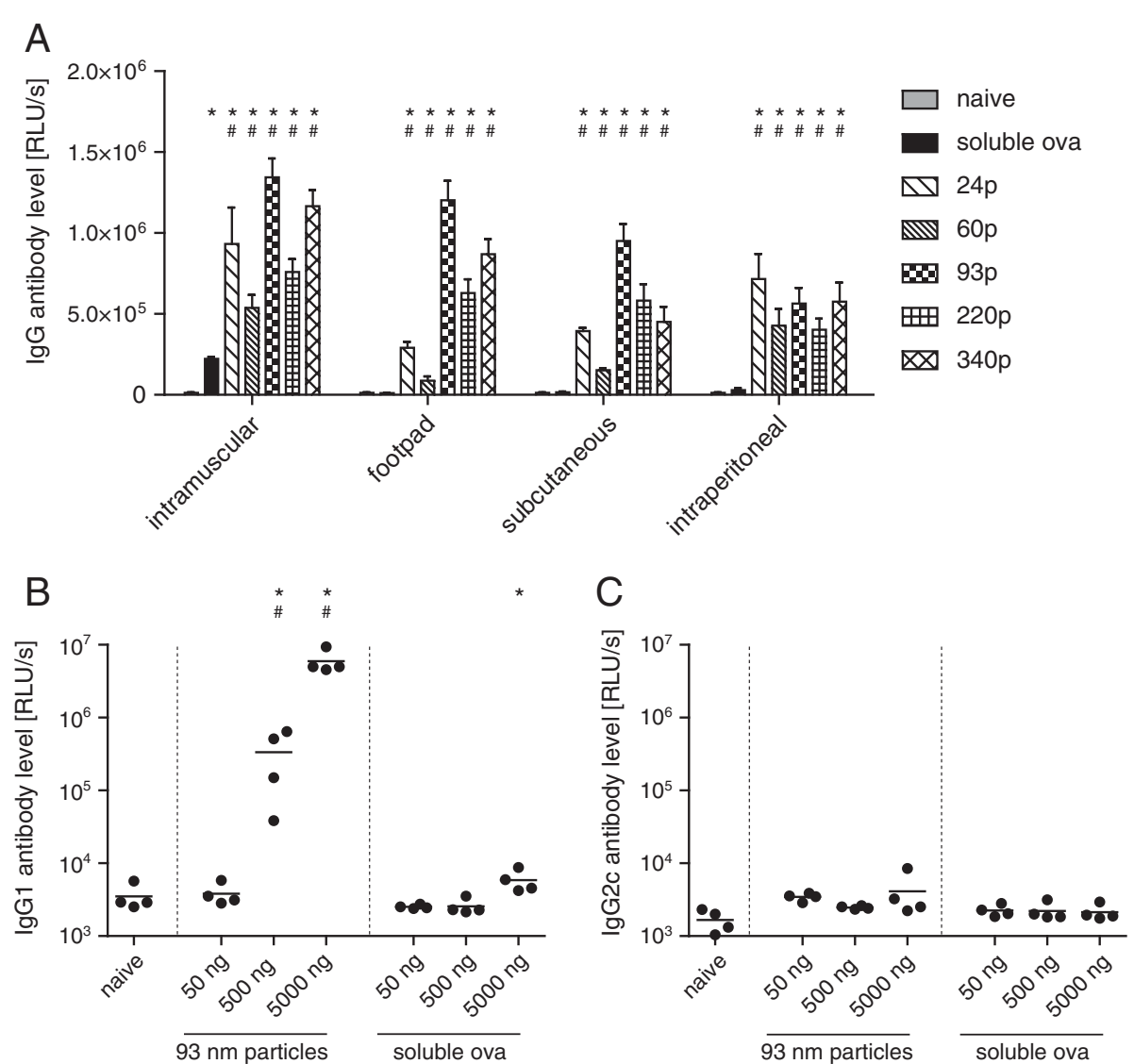

Figure 1 Immune response after immunization with ovalbumin loaded polystyrene particles. C57BL/6 mice were immunized once with $5 \mathrm{\mu g}$ soluble ovalbumin (ova), or ovalbumin-coated polystyrene particles of $24 \mathrm{~nm}$ (24p), $60 \mathrm{~nm}$ (60p), 93 nm (93p), $220 \mathrm{~nm}$ (220p), or 340 nm diameter (340p) carrying $5 \mathrm{\mu g}$ ovalbumin, either by intramuscular, footpad, subcutaneous or intraperitoneal injection. Two weeks after immunization ovalbumin specific lgG levels were determined luminometrically from 1:10000 dilutions of plasma by ELISA (A). To compare different amounts of protein, mice were immunized once by intramuscular injection with $50 \mathrm{ng}, 500 \mathrm{ng}$, or $5000 \mathrm{ng}$ of ovalbumin, either as soluble protein or coated on $93 \mathrm{~nm}$ polystyrene particles, and lgG1 (B) and lgG2C antibody titers (C) were analyzed in 1:100 dilution of plasma two weeks after immunization. Statistically significant differences compared to naive mice or mice immunized with the respective amount of soluble ovalbumin are indicated by * or \#, respectively $(P<0.05$, Student-Newman-Keuls method). The graphs show mean values of RLU/s (relative light units per second) and standard errors of the means of 4 (B, C) or 8 mice per group (A); data was acquired in two independent experiments. 
antibodies were detectable (data not shown), suggesting the necessity of $\mathrm{CD}^{+} \mathrm{T}$ cell help for antibody induction.

Adenoviral vectors are very popular tools for vaccine development and they are known to be highly immunogenic [9]. We compared immune responses induced by polystyrene particles loaded with ovalbumin with an adenoviral ovalbumin expression-display vector; this Ad5 vector Ad.pIXova encodes a fusion protein of the capsid protein IX and ovalbumin, and hence displays ovalbumin on the particle [5]. The ovalbumin content of Ad.pIXova was determined by ELISA to be $50 \mathrm{ng}$ per $10^{10}$ viral particles (vp; data not shown). To include a control for the influence of in vivo expression of ovalbumin from the adenoviral vector, a UV-inactivated [10] Ad.pIXova (UV-Ad ${ }^{\text {IIXova }}$ ) was included. Mice were immunized twice in a three-week interval by intradermal injection into the hind footpads with $50 \mathrm{ng}$ soluble ovalbumin, $50 \mathrm{ng}$ ovalbumin coupled to $24 \mathrm{~nm}, 93 \mathrm{~nm}$, or $340 \mathrm{~nm}$ polystyrene particles, or $10^{10} \mathrm{vp}$ Ad.pIXova or
UV-Ad ${ }^{\mathrm{pIXova}}$, equaling a protein delivery of $50 \mathrm{ng}$ ovalbumin; immune responses were analyzed three weeks after the second immunization.

Immunization of mice with active or inactivated adenoviral vectors resulted in detectable levels of both IgG1 and IgG2c type ovalbumin-binding antibodies (Figure 2A and $\mathrm{B}$ ). While the immunization with $50 \mathrm{ng}$ soluble ovalbumin did not induce detectable antibodies of either subtype, mice immunized with polystyrene particles carrying the same amount of ovalbumin exhibited binding antibody responses of mainly IgG1 type, with the highest response in mice immunized with $93 \mathrm{~nm}$ particles, which showed levels similar to mice immunized with UV-Ad ${ }^{\text {pIXova }}$.

For the analysis of cellular immune responses, splenocytes were isolated and restimulated in vitro with ovalbumin-derived peptides [11,12], and flow-cytometric analysis of intracellular cytokine levels was performed. The numbers of IFNY producing $\mathrm{CD}^{+}$(Figure $2 \mathrm{C}$ ) and
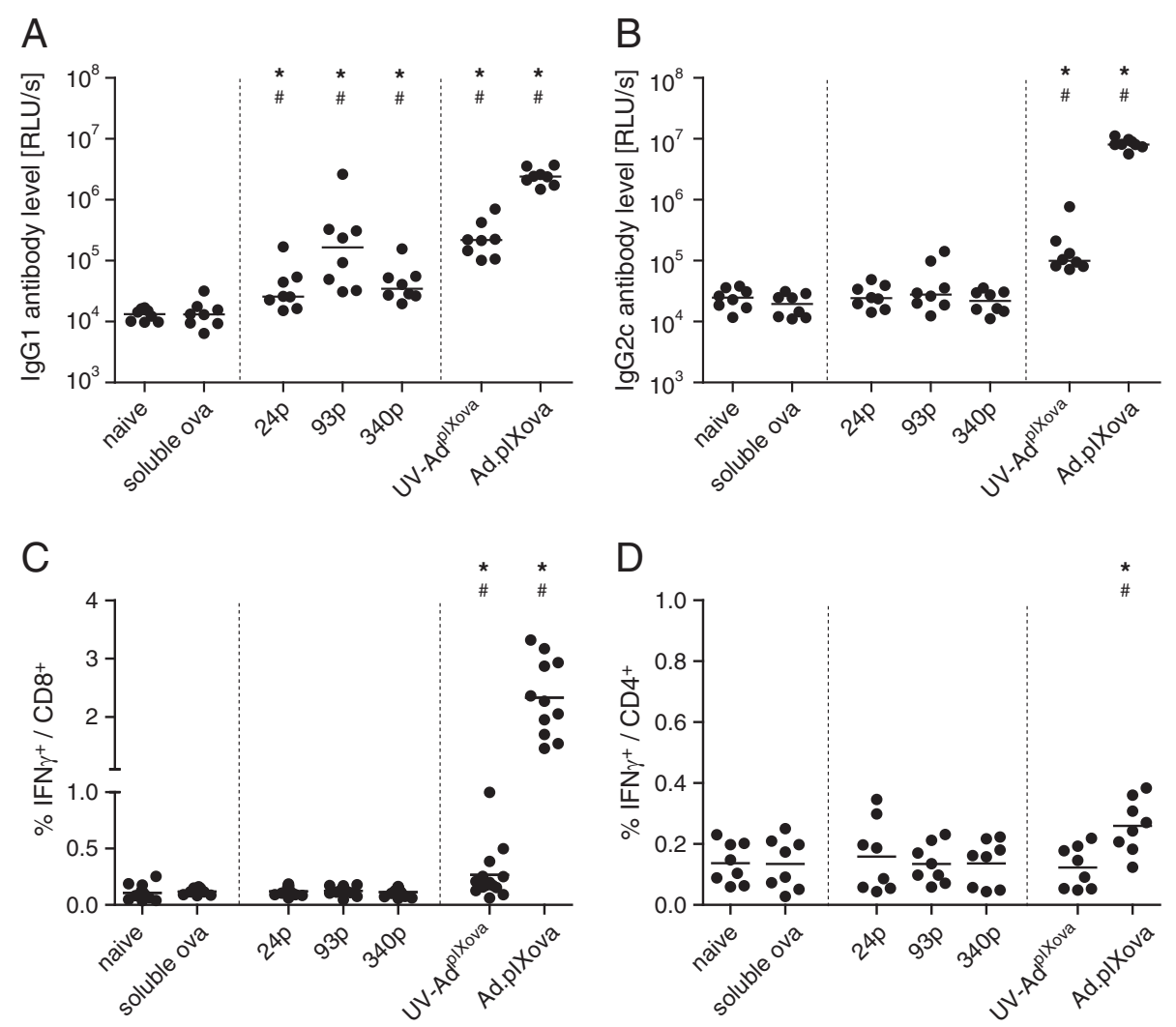

Figure 2 Immune response after immunization with ovalbumin loaded polystyrene particles or adenoviral vectors. C57BL/6 mice were immunized twice by intradermal injection into the hind footpads with $50 \mathrm{ng}$ soluble ovalbumin, ovalbumin-coated polystyrene particles of $24 \mathrm{~nm}$ (24p), $93 \mathrm{~nm}$ (93p) or $340 \mathrm{~nm}$ diameter (340p) carrying $50 \mathrm{ng}$ ovalbumin, or $10^{10} \mathrm{vp}$ ovalbumin-displaying adenovirus Ad.plXova or UV-Ad ${ }^{\text {plXova }}$. Three weeks after boost-immunization, ovalbumin binding lgG1 (A) and lgG2C antibody levels were analyzed from 1:100 dilutions of plasma (B). For analysis of cellular immune responses, spleen cells were isolated and restimulated in vitro with ovalbumin-specific peptides, and IFNY expression by $\mathrm{CD}^{+}(\mathbf{C})$ and $\mathrm{CD}^{+} \mathrm{T}$ cells $(\mathbf{D})$ was analyzed by flow cytometry. Statistically significant differences compared to naïve mice or mice immunized with soluble ovalbumin are indicated by * or \#, respectively $(P<0.05$, Student-Newman-Keuls method). The graphs show data of 8 mice per group that was acquired in two independent experiments, the bars indicate mean values. 
$\mathrm{CD}^{+} \mathrm{T}$ cells (Figure 2D) were highest in mice immunized with Ad.pIXova, and significantly lower when mice were immunized with the UV-inactivated UV-Ad ${ }^{\text {pIXova }}$ or polystyrene particles carrying $50 \mathrm{ng}$ ovalbumin. While there is a tendency to higher $\mathrm{CD} 8^{+} \mathrm{T}$ cell levels in mice immunized with UV-Ad ${ }^{\text {IIXova }}$ than polystyrene particles, the levels are comparable in these groups and underline the importance of antigen expression by the Ad vector for strong CTL induction, as well as for induction of $\mathrm{CD}^{+} \mathrm{T}$ cell responses, as was described before [5]. A similar trend was observed when the concentration of IL4 was analyzed in the supernatant of restimulated splenocytes, although the levels were rather low in all groups (data not shown).

As no relevant cellular immunity was induced by polystyrene particle immunization, we wanted to further assess the immunogenicity of the particles, and analyzed activation of and interferon production by dendritic cells (DCs) after uptake of ovalbumin-loaded particles or adenoviral vectors. Some low degree of activation of DCs was observed after loading with the largest, $220 \mathrm{~nm}$ and $340 \mathrm{~nm}$ polystyrene particles, whereas incubation with adenoviral particles led to DC activation comparable to stimulation with LPS (Figure 3A). Adenoviral particles also induced significant levels of interferon $\alpha$ and interferon $\beta$, but DCs incubated with soluble ovalbumin or ovalbumin-coated polystyrene particles did not produce interferons (Figure 3B). These findings confirm the inert nature of the polystyrene particles.

Comparing the immune responses induced by adenovirus-based immunization with immune responses induced by polystyrene particles loaded with a high amount of protein, i.e. $5 \mu \mathrm{g}$, it can be observed that the antibody levels that can be reached by immunization with protein-coated $93 \mathrm{~nm}$ particles are actually comparable in strength. It has been reported before that the particle size determines the induced immune response (reviewed in [13]), and our findings confirm this, as the best antibody response was found for the $93 \mathrm{~nm}$ particles, while only the smallest, $24 \mathrm{~nm}$ particles, that can
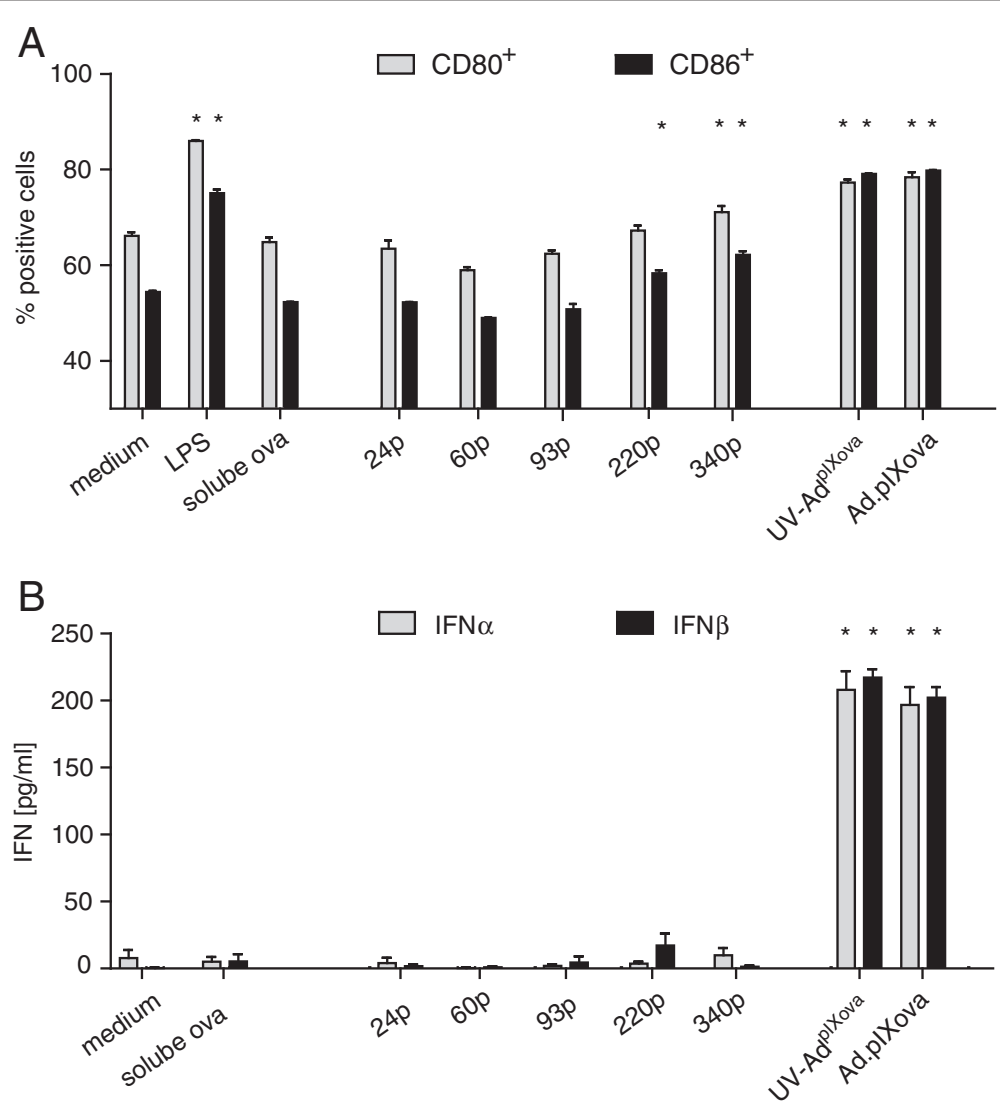

Figure 3 Activation of dendritic cells by ovalbumin-loaded particles. $5 \times 10^{5}$ bone-marrow derived DCs were co-incubated with $10 \mathrm{ng}$ soluble ovalbumin, polystyrene particles loaded with $10 \mathrm{ng}$ ovalbumin, or with $10^{9} \mathrm{vp} \mathrm{Ad.pIXova} \mathrm{or} \mathrm{UV-Ad}{ }^{\text {plXova }}$. Incubation with medium or lipopolysaccharide (LPS) was used as negative and positive controls, respectively. After $16 \mathrm{~h}$ co-incubation, cells were stained for expression of the activation markers CD80 and CD86 and analyzed by flow cytometry $(\mathbf{A})$. Supernatants of the cells were analyzed by ELISA for interferon a and $\beta$ concentrations (B). Statistically significant differences compared to untreated DCs are indicated by * $(P<0.05$, Student-Newman-Keuls method). 
most easily enter lymphatic structures on their own [14], could induce a significant, albeit low, $\mathrm{CD}^{+} \mathrm{T}$ cell response (data not shown).

Our results indicate that antigen coupling to polystyrene particles, although they are immunologically inert, induces enhanced antibody responses in comparison to immunization with soluble protein, and thus allows for the reduction of protein amount used for protein-based immunization. In contrast to adenoviral vectors, delivery on polystyrene particles does not change the antibody profile compared to protein immunization, which consists predominantly of IgG1 subtype antibodies.

We confirmed that polystyrene particles themselves are not immunogenic, having no particular effect on DC activation and cytokine production, thus they should be associated with very little risk of inducing autoimmunity as recently described for other vaccine adjuvants [15] (and reviewed in [16]). Rather, the enhancing effect of polystyrene particle delivery seems to rely mainly on the particulate nature and the size of the particles, as well as on the presentation of the antigen in an ordered array. Polystyrene particles are inert but not degradable, however, biodegradable particles such as dextran particles should be comparably adequate protein carriers and appropriate for use in humans. While the cellular immune response to adenoviral vectors was much higher than to antigen-coated polystyrene particles, in cases where protection can be conferred by humoral immunity, or for protein delivery in prime-boost combinations with viral vectors, particle-mediated delivery is an attractive option to efficiently and safely enhance immune responses to protein-based vaccines.

\section{Competing interest}

The authors declare that they have no conflict of interest.

\section{Authors' contributions}

$\llcorner J$ produced the vaccines and carried out the animal experiments and analyses. MT participated in the study design, data analysis and the drafting of the manuscript. RL, MS and TN participated in the animal experiments. OW designed the study and participated in the drafting of this manuscript. WB participated in the study design, data analysis, and drafted the manuscript. All authors read and approved the final manuscript.

\section{Acknowledgements}

This work was supported by grants from the Deutsche Forschungsgemeinschaft (DFG grants GRK 1045 to OW, WI 1329/6-1 to WB) and by a grant from the Krebshilfe to OW.

\section{Author details}

${ }^{1}$ Department of Molecular and Medical Virology, Ruhr-University Bochum, Bochum, Germany. ${ }^{2}$ Institute for Virology, University Hospital Essen, University Duisburg-Essen, Essen, Germany. ${ }^{3}$ Current address: Paul-Ehrlich-Institute, Langen, Germany.

Received: 27 September 2012 Accepted: 21 March 2013 Published: 5 April 2013

\section{References}

1. Baylor NW, Egan W, Richman P: Aluminum salts in vaccines-US perspective. Vaccine 2002, 20(Suppl 3):S18-S23.
2. Kalkanidis M, Pietersz GA, Xiang SD, Mottram PL, Crimeen-Irwin B, Ardipradja $K$, et al: Methods for nano-particle based vaccine formulation and evaluation of their immunogenicity. Methods 2006, 40:20-29.

3. Peek LJ, Middaugh CR, Berkland C: Nanotechnology in vaccine delivery. Adv Drug Deliv Rev 2008, 60:915-928.

4. Reddy ST, van der Vlies AJ, Simeoni E, Angeli V, Randolph GJ, O'Neil CP, et al: Exploiting lymphatic transport and complement activation in nanoparticle vaccines. Nat Biotechnol 2007, 25:1159-1164.

5. Bayer W, Tenbusch M, Lietz R, Johrden L, Schimmer S, Uberla K, et al: Vaccination with an adenoviral vector that encodes and displays a retroviral antigen induces improved neutralizing antibody and CD4+ T-cell responses and confers enhanced protection. J Viro/ 2010, 84:1967-1976.

6. Polysciences Inc. Technical Data Sheet 238C: Covalent coupling of proteins to carboxylated polystyrene microparticles by the "carbodiimide" method. Fishers, IN: Polysciences Inc; 2009.

7. Tenbusch M, Kuate S, Tippler B, Gerlach N, Schimmer S, Dittmer U, et al: Coexpression of GM-CSF and antigen in DNA prime-adenoviral vector boost immunization enhances polyfunctional CD8+ T cell responses, whereas expression of GM-CSF antigen fusion protein induces autoimmunity. BMC Immunol 2008, 9:13.

8. Cobbold SP, Jayasuriya A, Nash A, Prospero TD, Waldmann H: Therapy with monoclonal antibodies by elimination of T-cell subsets in vivo. Nature 1984, 312:548-551.

9. Liu Q, Muruve DA: Molecular basis of the inflammatory response to adenovirus vectors. Gene Ther 2003, 10:935-940.

10. Cotten M, Wagner E, Zatloukal K, Phillips S, Curiel DT, Birnstiel ML: Highefficiency receptor-mediated delivery of small and large 48 kilobase gene constructs using the endosome-disruption activity of defective or chemically inactivated adenovirus particles. Proc Natl Acad Sci USA 1992, 89:6094-6098.

11. Rotzschke O, Falk K, Stevanovic S, Jung G, Walden P, Rammensee HG: Exact prediction of a natural T cell epitope. Eur J Immunol 1991, 21:2891-2894.

12. Johnsen G, Elsayed S: Antigenic and allergenic determinants of ovalbumin-III. MHC la-binding peptide (OA 323-339) interacts with human and rabbit specific antibodies. Mol Immunol 1990, 27:821-827.

13. Bachmann MF, Jennings GT: Vaccine delivery: a matter of size, geometry, kinetics and molecular patterns. Nat Rev Immunol 2010, 10:787-796.

14. Manolova V, Flace A, Bauer M, Schwarz K, Saudan P, Bachmann MF: Nanoparticles target distinct dendritic cell populations according to their size. Eur J Immunol 2008, 38:1404-1413.

15. Nohynek H, Jokinen J, Partinen M, Vaarala O, Kirjavainen T, Sundman J, et al: AS03 Adjuvanted AH1N1 vaccine associated with an abrupt increase in the incidence of childhood narcolepsy in Finland. PLoS One 2012, 7:e33536.

16. Israeli E, Gmon-Levin N, Blank M, Shoenfeld Y: Adjuvants and autoimmunity. Lupus 2009, 18:1217-1225.

doi:10.1186/1743-422X-10-108

Cite this article as: Johrden et al:: Comparison of polystyrene nanoparticles and UV-inactivated antigen-displaying adenovirus for vaccine delivery in mice. Virology Journal 2013 10:108.

\section{Submit your next manuscript to BioMed Central and take full advantage of:}

- Convenient online submission

- Thorough peer review

- No space constraints or color figure charges

- Immediate publication on acceptance

- Inclusion in PubMed, CAS, Scopus and Google Scholar

- Research which is freely available for redistribution 